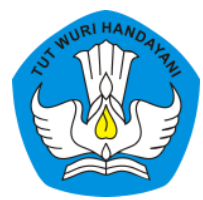

Page: $71-90$

\title{
MEDIA POTBANGTAR MENINGKATKAN HASIL BELAJAR MENGHITUNG LUAS BANGUN DATAR PADA SISWA SEKOLAH DASAR
}

\author{
Istafada \\ Sekolah Dasar Negeri Miji 4,Kota Mojokerto, Jawa Timur, Indonesia \\ Contributor Email: istafadafida@gmail.com
}

Received: Feb 12, 2021

Accepted: Mar 16, 2021

Published: Mar 30, 2021

Article Url: https://ojsdikdas.kemdikbud.go.id/index.php/didaktika/article/view/283

\begin{abstract}
Lack of understanding mathematical concepts that students accept will lead to low student learning outcomes. Teachers as a learning resource are obliged to provide creative learning environment for students in the classroom. One of the activities must be carried out by the teacher is selecting and determining appropriate media for learning. The objective of this research to determine improved learning outcomes in calculating area of flat shape using potbangtar media. This research uses two rounds of action research. Each round consists of 4 stages, namely design, activity, observation, reflection and revision. The data obtained are in the form of evaluation test results, observation sheets of teaching and learning activities. From the results of data analysis found that student learning outcomes increased from cycle I to cycle II, from 75.61 to 80.49 and student learning completeness also increased from cycle I $(85.37 \%)$ to cycle II to $(95.12 \%)$ ). We can conclude that the usage of potbangtar media to calculate the area of flat shape is very effective so that the learning outcomes of the fifth grade students of SDN MIJI 4, Mojokerto increase.
\end{abstract}

Keywords: Potbangtar Media; Learning Outcomes; 


\begin{abstract}
Abstrak
Kurangnya pemahaman konsep matematika yang diterima siswa akan menyebabkan hasil belajar matematika siswa juga rendah. Guru sebagai salah satu sumber belajar berkewajiban menyediakan lingkungan belajar yang kreatif bagi siswa di kelas. Salah satu kegiatan yang harus dilakukan guru adalah memilih dan menentukan media yang sesuai dengan pembelajarannya. Pada penelitian ini mempunyai tujuan mengetahui peningkatan hasil belajar dalam menghitung luas bangun datar dengan menggunakan media potbangtar. Penelitian ini menggunakan penelitian tindakan (action research) sebanyak dua putaran. Setiap putaran terdiri dari 4 tahap yaitu rancangan, kegiatan dan pengamatan, refleksi dan revisi. Data yang diperoleh berupa hasil tes evaluasi dan lembar observasi kegiatan belajar mengajar. Dari hasil analisis data didapatkan bahwa hasil belajar siswa meningkat dari siklus I ke siklus II, yaitu 75,61 ke 80,49 dan ketuntasan belajar siswa juga mengalami peningkatan dari siklus I $(85,37 \%)$ ke siklus II menjadi (95,12\%). Simpulan dari penelitian ini adalah penggunaan media potbangtar dalam pembelajaran menghitung luas bangun datar sangat efektif sehingga hasil belajar siswa kelas V SDN MIJI 4 kota Mojokerto meningkat.
\end{abstract}

Kata Kunci: Hasil Belajar; Media Potbangtar;

\title{
A. Pendahuluan
}

Menanamkan konsep dasar Matematika di SD adalah merupakan fondasi dalam pembelajaran matematika. Guru sebagai salah satu sumber belajar berkewajiban menyediakan lingkungan belajar yang kreatif bagi kegiatan belajar siswa di kelas. Salah satu kegiatan guru yang harus dilakukan adalah memilih dan menentukan metode dan media yang akan digunakan dalam pembelajaran. Pemilihan dan penentuan ini didasari adanya kreatifitas guru dalam mencapai tujuan pembelajarannya.

Kurangnya pemahaman konsep matematika yang diterima siswa akan menyebabkan hasil belajar matematika siswa juga rendah. Hal ini bisa ditunjukkan dalam proses pembelajaran yang hanya menuntut siswa untuk menghafalkan setiap rumus tanpa siswa tahu cara mendapatkan rumus itu, maka akan menyebabkan siswa mudah lupa dan bahkan tidak mengerti dengan rumus yang ada.

Kenyataan yang terjadi di kelas V SDN Miji 4 Kota Mojokerto Tahun pelajaran 2018/2019 hasil belajar siswa dalam menghitung luas 
bangun datar masih di bawah KKM. Dari 41 siswa ada 30 siswa yang mendapatkan nilai kurang dari 70 dan hanya 11 siswa yang sudah mencapai $\mathrm{KKM} \geq 70$.

Penyebab dari rendahnya hasil belajar siswa kelas V SDN MIJI 4 Kota Mojokerto dalam menghitung luas bangun datar ada beberapa hal diantaranya adalah (1) guru menggambarkan bangun datar di papan tulis untuk menurunkan rumus luas bangun datar membutuhkan waktu, (2) pembelajaran tidak bermakna, karena siswa langsung di beri rumus luas bangun datar untuk menghitung luas bangun datar tanpa tahu dari mana asal rumus tersebut, dan (3) Motivasi siswa dalam belajar matematika terutama menghitung luas bangun datar masih rendah. Faktor guru juga menjadi penentu dalam hasil belajar siswa. Terutama jika guru kurang tepat dalam memilih media dan model pembelajaran yang dapat menyebabkan rendahnya hasil belajar siswa.

Oleh karena itu penulis berharap agar masalah tersebut dapat terselesaikan dengan baik, maka penulis menggunakan media potbangtar dalam proses belajar mengajar matematika. Arsyad (2011) mengemukakan, "Media pembelajaran dapat membantu meningkatkan pemahaman dan memudahkan penafsiran yang akhirnya dapat meningkatkan hasil belajar siswa". Sesuai dengan penelitian sebelumnya menurut Suprijono (2010), salah satu fungsi media antara lain dapat menanamkan konsep dasar yang benar, konkret, dan realistis, dan memberikan pengalaman yang menyeluruh dari yang konkret sampai abstrak.

Dari sini jelas bahwa media sangat penting untuk interaksi guru dengan siswa dalam proses pembelajaran, sehingga tujuan dari pembelajaran tersebut dapat tercapai dan siswa memperoleh hasil yang memuaskan. Media pembelajaran yang diterapkan guru di sini adalah dalam upaya meningkatkan hasil belajar dan bisa digunakan untuk mengurangi serta menghilangkan anggapan siswa hanya menghafal rumus yang telah disajikan atau disuguhkan oleh guru tanpa tahu dari mana rumus tersebut berasal. 
Tujuan utama yang ingin dicapai dalam kegiatan pembelajaran adalah hasil belajar. Hasil belajar digunakan untuk mengetahui sebatas mana siswa dapat memahami serta mengerti materi tersebut. Seperti yang dikemukakan Jihad dan Haris (2012: 14) bahwa hasil Belajar adalah merupakan pencapaian bentuk perubahan perilaku yang cenderung menetap dari ranah kognitif, afektif, dan psikomotoris serta proses belajar yang dilakukan dalam waktu tertentu. Jadi, hasil belajar menurut penulis di sini adalah hasil belajar yang diperoleh dari hasil evaluasi atau tes tulis setelah dilakukan pembelajaran yang dinyatakan dalam bentuk nilai atau skor.

Permasalahan yang dikemukakan dalam penelitian ini adalah bagaimanakah media potbangtar dalam meningkatkan hasil belajar menghitung luas bangun datar pada siswa kelas V Sekolah Dasar Negeri MIJI 4 kota Mojokerto? Sesuai permasalahan tersebut penelitian ini bertujuan untuk mengetahui media potbangtar dalam meningkatkan hasil belajar siswa dalam menghitung luas bangun datar pada siswa kelas $\mathrm{V}$ Sekolah Dasar Negeri MIJI 4 kota Mojokerto.

Manfaat penelitian ini bagi siswa, antara lain memberikan sajian yang menarik dalam pembelajaran dan memperlihatkan tahap perkembangan belajar siswa sehingga dapat meningkatkan hasil belajar siswa. Bagi guru merupakan upaya untuk perbaikan dan peningkatan layanan profesional dalam menangani proses mengajar di kelas.

\section{B. Metode}

Pelaksanaan penelitian ini hanya dikenakan pada siswa kelas $\mathrm{V}$ dengan jumlah siswa 41, bertempat di SDN MIJI 4 Jalan Wahid Hasyim No 20 kecamatan Kranggan kota Mojokerto tahun pelajaran 2018/2019. Penelitian ini dilakukan pada tanggal 2 Oktober 2018 (siklus I) dan siklus II pada 9 Oktober 2018 materi Menghitung Luas Bangun Datar.

Penelitian ini menggunakan 3 instrumen, yaitu (a) Instrumen aktivitas guru dan siswa / kualitas pembelajaran, (b) Instrumen observasi siswa, (c) Instrumen hasil evaluasi (penilaian pengetahuan/tes tulis) yang dikerjakan individu yaitu untuk mengetahui keberhasilan/ ketuntasan 
belajar siswa pelaksanaanya di akhir kegiatan inti, yang merupakan tes buatan guru. Seperti yang dikemukakan Arikunto (2012) bahwa tes buatan guru mempunyai fungsi untuk (a) menentukan sejauh mana siswa telah menguasai bahan pelajaran yang telah diberikan, (b) menentukan apakah tujuan sudah tercapai, dan (c) memperoleh suatu nilai.

Dalam penelitian ini, pokok bahasan dianggap tuntas secara klasikal, jika nilai yang didapat siswa 70 lebih dari atau sama dengan 85 $\%$. Siswa dinyatakan tuntas belajar menghitung bangun datar jika mendapat nilai minimum 70 .

Model penelitian yang digunakan peneliti adalah model penelitian tindakan dari Kemmis dan Taggart (1988) yaitu dalam prosedur penelitian terdapat empat tahap kegiatan pada setiap siklus. 4 tahap tersebut adalah (1) planning (perencanaan), (2) action (tindakan), (3) observation(pengamatan, dan (4) reflection (refleksi).

Analisis dan pengolahan data dilakukan dengan menggunakan teknik data deskriptif kualitatif baik yang bersifat linier (mengalir) maupun bersifat sirkuler. Rumus yang digunakan dalam menganalisis dan mengolah data diantaranya sebagai berikut.

1. Mencari rata-rata hasil belajar.

Rumusnya: $X=\frac{\text { Jumlah Nilai }}{\text { Jumlah Siswa }}$

Rumus ini digunakan untuk mencari perkembangan dan peningkatan hasil belajar siswa jika dikomparatifkan dari siklus I ke siklus berikutnya.

2. Mencari persentase (\%)

Rumusnya: $\%=\frac{\text { Jumlah selisih nilai yang di peroleh }}{\text { Jumlah nilai yang diperoleh sebelumnya }} \times 100 \%$

Rumus ini digunakan untuk mengetahui dan menentukan sejauh mana perkembangan dan peningkatan hasil belajar yang telah dicapai siswa.

3. Mencari Ketuntasan Belajar Klasikal

Rumus:

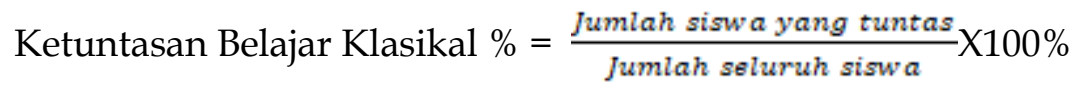


Rumus ini digunakan untuk siswa tergolong tuntas atau tidak pada materi tersebut dengan tolak ukurnya adalah KKM (Kriteria Ketuntasan Minimum) yang telah ditetapkan oleh guru dalam penelitian ini adalah 70 .

\section{Hasil dan Pembahasan}

Pada penelitian ini siswa dinyatakan tuntas belajar dalam menghitung luas bangun datar dalam pembelajaran menggunakan media potbangtar jika nilai yang didapat siswa minimum 70 dan suatu pokok bahasan dianggap tuntas secara individu atau klasikal jika nilai yang didapat siswa 70 lebih dari atau sama dengan $85 \%$.

\section{Hasil}

Hasil yang didapat dalam penelitian ini mengacu pada model penelitian tindakan yang terdiri dari 4 tahapan setiap siklusnya seperti uraian berikut.

\section{Hasil Penelitian Siklus I}

a. Planning (Perencanaan),

Pada tahap ini peneliti menyiapkan perangkat pembelajaran antara lain: rencara pelaksanaan pembelajaran I, media potbangtar, soal evaluasi I, instrumen observasi siswa untuk kegiatan pembelajaran I, dan instrumen observasi kualitas pembelajaran/ aktivitas guru dan siswa I serta alat -alat pembelajaran yang mendukung

\section{b. Action (Tindakan)}

Kegiatan pembelajaran untuk siklus I dilaksanakan bersamaan dengan pelaksanaan pembelajaran. Proses pelaksanaan pembelajaran menghitung luas bangun datar menggunakan media potbangtar ada 3 tahap, yaitu tahap pengenalan media potbangtar, menemukan atau menurunkan rumus luas bangun datar, dan menghitung luas bangun datar. 
1) Tahap pengenalan media potbangtar.

Pada tahap ini guru menunjukkan media potbangtar, mulai dari nama media potbangtar (yaitu singkatan dari potongan bangun datar), menunjukkan 3 komponen utama media potbangtar yang terdiri dari papan berkarpet (fungsinya untuk menempel potongan bangun datar), papan tulis/white board (fungsinya untuk menuliskan penurunan rumus luas bangun datar), dan beberapa bentuk bangun datar yang berwarnawarni (sebagai proses dalam menurunkan rumus luas bangun datar). Seperti tampak pada gambar berikut.

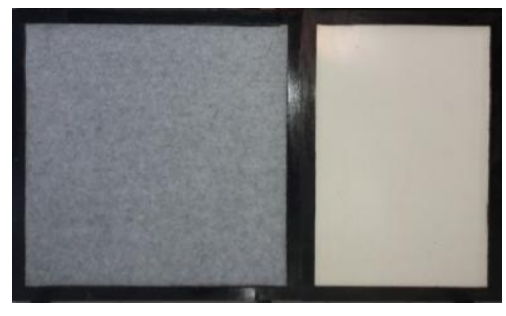

Gambar 1: Komponen 1 dan 2

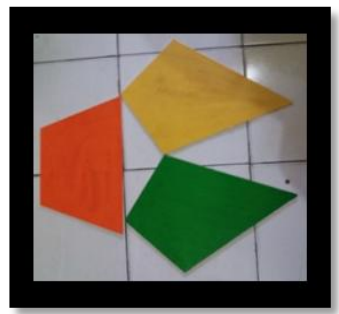

Gambar 2: Komponen 3

Media potbangtar ini jika digunakan dalam pembelajaran akan tampak seperti gambar berikut.

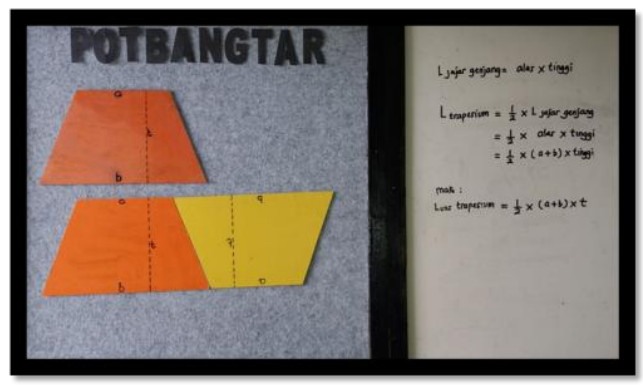

Gambar 3: Media Potbangtar

2) Tahap menemukan atau menurunkan rumus luas bangun datar. Pada tahap ini siswa secara berkelompok dengan bimbingan guru mengerjakan lembar kerja yang merupakan urutan atau langkah-langkah untuk menemukan rumus luas bangun datar. Seperti tampak pada gambar berikut. 


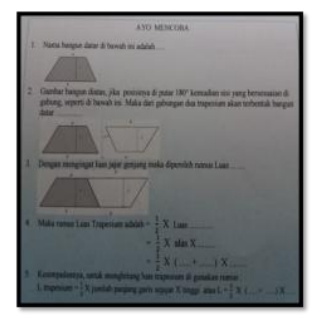

Gambar 4: LK1

2) Tahap menghitung luas bangun datar.

Pada tahap ini setelah siswa secara berkelompok menurunkan atau menemukan rumus luas bangun datar, siswa kemudian menghitung luas bangun dengan menggunakan rumus. Seperti gambar berikut.

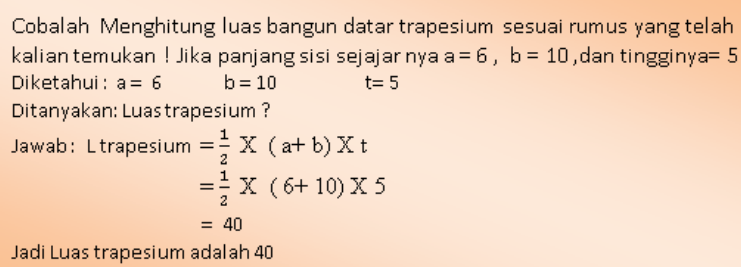

Gambar 5 penggunaan rumus

Pada akhir pembelajaran siswa diberi tes tulis/ evaluasi dengan tujuan untuk mengetahui tingkat keberhasilan dalam proses pembelajaran menggunakan media potbangtar dalam menghitung luas bangun datar. Instrumen yang digunakan adalah tes evaluasi I. Dari data rata-rata hasil belajar siklus I terlihat ada peningkatan meskipun kenaikannya belum signifikan mulai dari rata-rata hasil belajar siswa dari sebelum menggunakan media potbangtar yang hanya 60 di siklus 1 meningkat 75,61, dan siswa yang tuntas sebanyak 35 dari 41 siswa. Sedangkan ketuntasan belajar siswa juga sudah meningkat 85,37\% persentase ketuntasan ini sudah sesuai dengan yang ditetapkan yaitu $85 \%$.

Rekap rata-rata hasil belajar siswa pada pembelajaran menghitung luas bangun datar menggunakan media potbangtar siklus I, tampak pada tabel berikut. 
Tabel 1: Rekap Hasil Belajar Siklus 1 Setelah Menggunakan Media Potbangtar

\begin{tabular}{clc}
\hline No & \multicolumn{1}{c}{ Uraian } & Hasil \\
\hline 1 & Nilai rata-rata hasil belajar & 75,61 \\
2 & Jumlah siswa yang tuntas belajar & 35 \\
3 & Presentase ketuntasan belajar & 85,37 \\
\hline
\end{tabular}

c. Observation (Pengamatan)

Hasil observasi pada siklus I yang dilaksanakan oleh guru pada pembelajaran menghitumg luas bangun datar menggunakan media potbangtar mendapatkan penilaian yang cukup baik dari pengamat. Dari nilai keseluruhan hanya terdapat beberapa nilai kurang baik. Namun demikian penelitian tersebut belum merupakan hasil yang optimal. Untuk itu ada beberapa aspek yang perlu mendapatkan perhatian untuk menyempurnakan proses pembelajaran dengan menggunakan media potbangtar selanjutnya. Aspek-aspek tersebut antara lain, memotivasi siswa, membimbing siswa merumuskan kesimpulan/ menemukan konsep, dan pengolahan waktu. Dari lembar observasi atau instrument aktivitas guru dan siswa dalam pembelajaran menggunakan media potbangtar dalam menghitung luas bangun datar terlihat pada siklus I seperti pada tabel berikut.

Tabel 2: Pengelolaan pembelajaran Siklus 1 menerapkan media Potbangtar

\begin{tabular}{|c|c|c|}
\hline No & Aspek yang diamati & Penilaian \\
\hline & $\begin{array}{l}\text { Pengamatan KBM } \\
\text { A. Pendahuluan } \\
\text { 1. Motivasi siswa } \\
\text { 2. Menyampaikan tujuan pembelajaran }\end{array}$ & $\begin{array}{l}2 \\
3\end{array}$ \\
\hline I & $\begin{array}{l}\text { B. Kegiatan Inti } \\
\text { 1. Mendiskusikan langkah-langkah kegiatan bersama } \\
\text { siswa. } \\
\text { 2. Membimbing siswa melakukan kegiatan } \\
\text { 3. Membimbing siswa mendiskusikan hasil kegiatan } \\
\text { dalam kelompok } \\
\text { 4. Memberikan kesempatan pada siswa untuk } \\
\text { mempresentasikan hasil kegiatan belajar mengajar }\end{array}$ & $\begin{array}{l}3 \\
3\end{array}$ \\
\hline
\end{tabular}




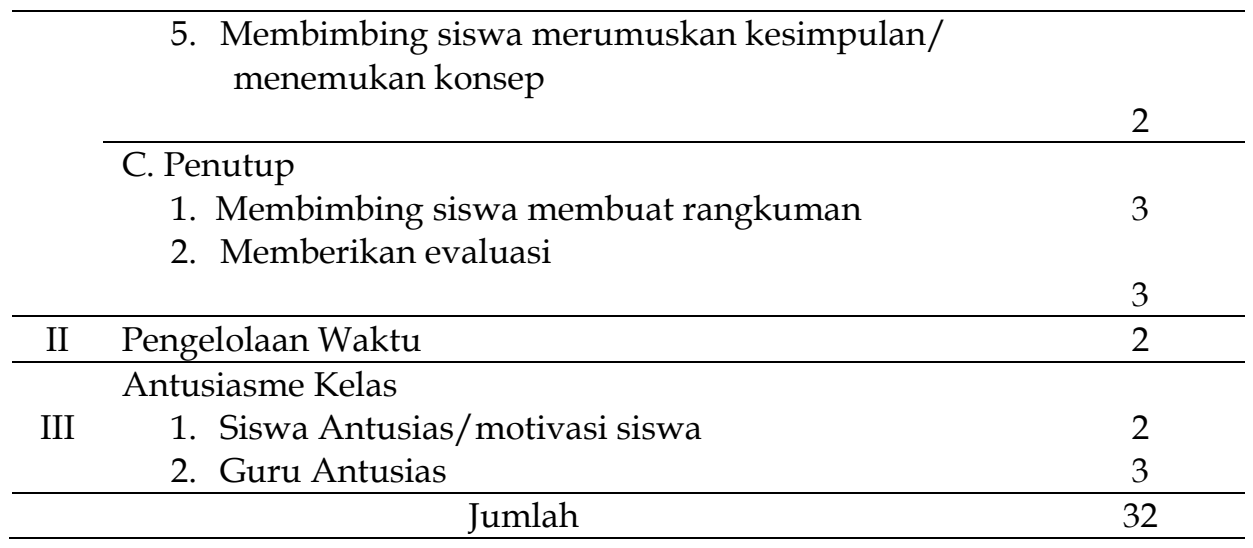

Keterangan :

Nilai dan Kriteria

1. Tidak baik

2. Kurang baik

3. Cukup baik

4. Baik

d. Reflection (Refleksi)

Pada kegiatan pembelajaran di siklus I diperoleh informasi dari hasil pengamatan masih terdapat kekurangan terutama dalam hal memotivasi siswa, membimbing siswa dalam menemukan rumus, dan pengolahan waktu. Untuk itu perlu adanya revisi rancangan pelaksanaan pembelajaran pada siklus I antara lain dengan (1) Meningkatkan proses pembelajaran yang bisa membuat siswa lebih termotivasi dalam pembelajaran; (2) Meningkatkan pembimbingan siswa untuk menemukan rumus luas bangun datar; dan (3) Mendistribusikan waktu secara baik sehingga kegiatan pembelajaran dapat berjalan sesuai dengan yang diharapkan.

\section{Hasil Penelitian Siklus II}

a. Planning (Perencanaan)

Pada siklus sebelumnya (siklus I) masih terdapat kekurangan, sehingga peneliti melakukan perbaikan dengan cara tanya jawab kesulitan siswa dalam pembelajaran menggunakan media potbangtar 
untuk menghitung luas bangun datar. Kemudian dari hasil jawaban siswa tersebut digunakan peneliti menyiapkan rancangan pelaksanaan pembelajaran yang membuat siswa lebih termotivasi dalam belajar. Tidak hanya itu peneliti juga akan menggunakan waktu secara baik atau efektif dalam kegiatan pembelajaran mulai dari pendahuluan, kegiatan inti dan penutupnya sehingga kegiatan pembelajaran di siklus II ini dapat berjalan sesuai dengan yang diharapkan. Selain itu peneliti juga menyiapkan lembar observasi kualitas pembelajaran/ aktivitas guru dan siswa II untuk pelaksanaan di tindakan pada siklus II.

\section{b. Action (Tindakan)}

Proses pembelajaran mengacu pada rencana pembelajaran II yang telah direvisi dan pelaksanaannya seperti pada tahap perencanaan siklus I. Adapun pelaksanaannya melalui 3 tahapan berikut ini.

1) Tahap pengenalan media potbangtar.

Seperti halnya pada siklus I, tahap ini peneliti mengingatkan kembali komponen-komponen media potbangtar pada siswa, agar pembelajaran menggunakan media potbangtar lebih mudah diterima oleh siswa dan tujuan pembelajaran akan tercapai sesuai yang diharapkan. Seperti tampak pada gambar berikut.

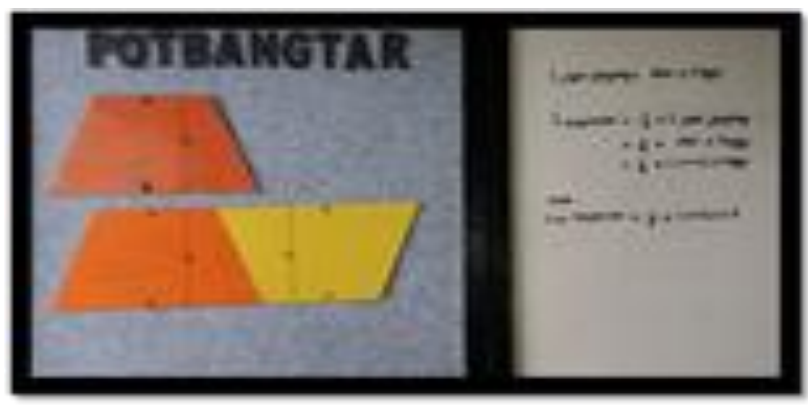

Gambar 6: Media Potbangtar

2) Tahap menemukan atau menurunkan rumus luas bangun datar

Pada tahap ini siswa secara berkelompok dengan bimbingan guru mengerjakan lembar kerja yang merupakan urutan atau langkah-langkah 
untuk menemukan rumus luas bangun datar. Seperti tampak pada gambar berikut.

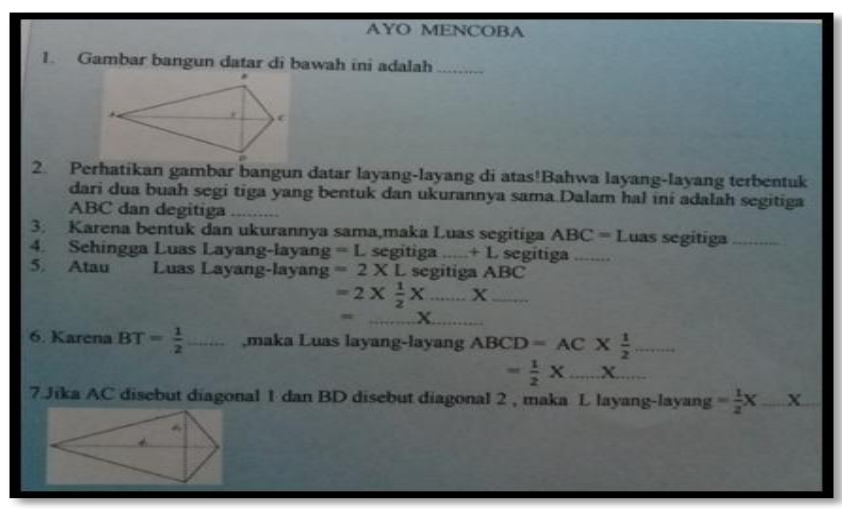

Gambar 7. LK2

3) Tahap menghitung luas bangun datar

Pada tahap ini setelah siswa secara berkelompok menurunkan atau menemukan rumus luas bangun datar, siswa kemudian menghitung luas bangun datar dengan menggunakan rumus. Seperti gambar berikut.

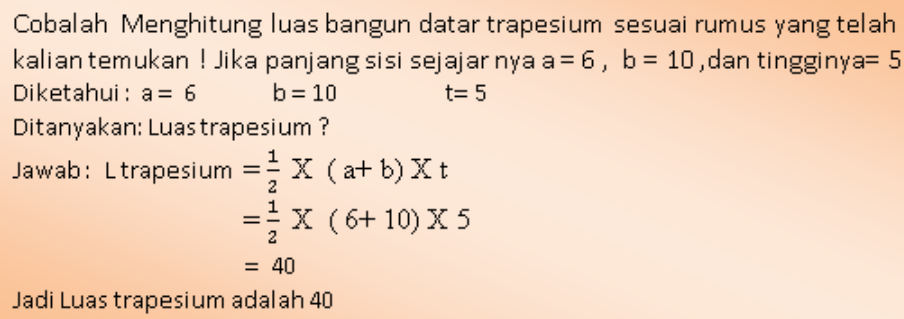

Gambar 8: Penggunaan Rumus

Pada akhir pembelajaran siswa diberi tes tulis atau evaluasi II dengan tujuan untuk mengetahui tingkat keberhasilan dalam proses pembelajaran dengan menggunakan media potbangtar dalam menghitung luas bangun datar. Instrumen yang yang digunakan adalah evaluasi II. Dari hasil evaluasi yang dilaksanakan pada siklus II dapat diinformasikan siswa terlihat antusias dalam mengerjakan tugas, dalam bekerja sama menemukan rumus atau konsep, sehingga terlihat dari hasil tes evaluasinya ada peningkatan rata-rata hasil belajar siswa di siklus II 
yaitu 80,49, siswa yang tuntas belajar mencapai 39 siswa, sedangkan ketuntasan belajar siswa mencapai 95,12\%. Persentasi ketuntasan ini sudah melebihi kategori ketuntasan belajar siswa yang telah ditetapkan yaitu $85 \%$. Rekap rata-rata hasil belajar siswa dalam pembelajaran menghitung luas bangun datar menggunakan media potbangtar, tampak pada tabel berikut.

Tabel 3: Rekap Hasil Belajar Siklus II setelah menggunakan media Potbangtar

\begin{tabular}{clc}
\hline No & \multicolumn{1}{c}{ Uraian } & Hasil \\
\hline 1 & Nilai rata-rata hasil belajar & 80,49 \\
2 & Jumlah siswa yang tuntas belajar & 39 \\
3 & Presentase ketuntasan belajar & 95,12 \\
\hline
\end{tabular}

\section{c. Observation (Pengamatan)}

Dari hasil pengamatan (observasi) tampak aspek yang diamati pada kegiatan pembelajaran siklus II yang dilaksanakan oleh guru dengan menggunakan media potbangtar beberapa aspek mendapatkan penilaian cukup baik terutama dalam membimbing siswa menemukan rumus luas bangun datar, memotivasi siswa dalam pembelajaran dan mengelola waktu yang efektif. Untuk aspek yang lain juga mengalami peningkatan antara lain antusias siswa, siswa lebih berani mengemukakan atau mengajukan pendapat.

Adapun aktivitas siswa yang paling dominan pada siklus II ini adalah kerja sama dengan kelompok, mendengarkan atau memperhatikan pelajaran guru, dan membaca buku. Untuk analisis atau rekap hasil pengelolaan pembelajaran pada siklus II dengan menggunakan media potbangtar dapat dilihat pada tabel berikut.

Tabel 4: Pengelolaan Pembelajaran Siklus II dengan Menerapkan Media Potbangtar

\begin{tabular}{clc}
\hline No & \multicolumn{1}{c}{ Aspek yang diamati } & Penilaian \\
\hline I & $\begin{array}{l}\text { Pengamatan KBM } \\
\text { A.Pendahuluan }\end{array}$ \\
\hline
\end{tabular}




\begin{tabular}{|c|c|c|}
\hline & 1. Motivasi siswa & 4 \\
\hline & B. Kegiatan Inti & \\
\hline & $\begin{array}{l}\text { 1. Mendiskusikan langkah-langkah kegiatan } \\
\text { bersama siswa. }\end{array}$ & 3 \\
\hline & 2. Membimbing siswa melakukan kegiatan & \\
\hline & 3. Membimbing siswa mendiskusikan hasil & 4 \\
\hline & 4. Memberikan kesempatan pada siswa untuk & 4 \\
\hline & mengajar & 3 \\
\hline & 5. Membimbing siswa merumuskan & \\
\hline & kesimpulan / menemukan konsep & 4 \\
\hline & C. Penutup & \\
\hline & 1. Membimbing siswa membuat rangkuman & 4 \\
\hline & & 3 \\
\hline II & Pengelolaan Waktu & 4 \\
\hline & Antusiasme Kelas & \\
\hline III & 3. Siswa Antusias/motivasi siswa & 4 \\
\hline & 4. Guru Antusias & 4 \\
\hline
\end{tabular}

Keterangan :

Nilai dan Kriteria

1. Tidak baik

2. Kurang baik

3. Cukup baik

4. Baik

Dari tabel tersebut diatas terlihat bahwa aspek pada siklus I nilainya masih cukup baik di siklus II sudah mendapatkan nilai atau predikat baik. Aspek-aspek tersebut antara lain, memotivasi siswa, membimbing menemukan rumus, dan mengelola waktu dalam pembelajaran. Adanya peningkatan pada hasil belajar pada siklus II ini dipengaruhi oleh peningkatan kemampuan guru dalam menggunakan atau menerapkan media potbangtar dalam pembelajaran menghitung luas 
bangun datar sehingga siswa lebih mudah dalam menghitung luas bangun datar.

\section{d. Reflection (Refleksi)}

Pada siklus II ini temuan yang diperoleh oleh peneliti antara lain (1) pembelajaran berlangsung dengan baik. Meskipun ada beberapa aspek yang belum sempurna, persentase pelaksanaannya untuk masing-masing aspek sudah baik; (2) Berdasarkan data hasil pengamatan, diketahui bahwa siswa aktif selama proses pembelajaran berlangsung; (3) Kekurangan pada siklus sebelumnya sudah mengalami perbaikan dan peningkatan, sehingga menjadi lebih baik; dan (4) Rata-rata hasil belajar, jumlah siswa yang tuntas, dan ketuntasan belajar siswa pada siklus II juga mengalami peningkatan.

Revisi pelaksanaan pada siklus II peneliti telah menerapkan pembelajaran dengan menggunakan media potbangtar dengan baik, dapat dilihat dari aktivitas siswa serta rata-rata hasil belajar siswa dalam pelaksanaan proses pembelajaran sudah berjalan dengan baik. Maka tidak diperlukan revisi terlalu banyak. Tetapi yang perlu diperhatikan untuk tindakan selanjutnya adalah memaksimalkan dan mempertahankan apa yang telah ada agar pada pelaksanaan proses pembelajaran selanjutnya dengan menggunakan media potbangtar dalam menghitung luas bangun datar hasil belajar siswa lebih meningkat dan tujuan pembelajaran dapat tercapai.

\section{Pembahasan}

Sebelum pelaksanaan Tindakan kelas dengan menggunakan media potbangtar, guru melaksanakan pembelajaran hanya memberikan rumus yang sudah jadi. Akibatnya, sehingga siswa tidak tahu dari mana rumus tersebut berasal. Pembelajaran masih dilakukan secara klasikal dan konvensional. Guru sudah menggunakan media tetapi hanya sebatas gambar saja, sehingga siswa tidak terlibat secara aktif dan masih berpusat pada guru dalam pembelajaran. Pada penelitian kali ini pembelajaran 
menghitung luas bangun datar dengan menggunakan media potbangtar akan dapat menghilangkan asumsi bahwa pembelajaran berpusat pada guru, guru hanya memberikan rumus yang sudah jadi , dan siswa tidak terlibat secara aktif. Sesuai dengan salah satu fungsi media adalah menjadikan pembelajaran menarik dan mengarahkan perhatian siswa untuk berkonsentrasi terhadap materi pelajaran yang ditampilkan (Wati, 2016). Asyar (2012: 8) juga mengatakan bahwa, "Media pembelajaran dapat dipahami sebagai segala sesuatu yang dapat menyampaikan atau menyalurkan pesan dari sumber secara terencana, sehingga terjadi lingkungan belajar yang kondusif dimana penerimanya dapat melakukan proses belajar secara efisien dan efektif". Dari sini peneliti mempunyai keyakinan pembelajaran menghitung luas bangun datar dengan menggunakan media potbantar akan dapat merubah asumsi negatif tersebut khususnya hasil belajar siswa akan dapat meningkat.

Setelah dilakukan perbaikan pembelajaran dengan menggunakan media Potbangtar dan diterapkan dalam pembelajaran menghitung luas bangun datar, terlihat perubahan yang signifikan mulai dari aktivitas siswa dan keaktivan siswa atau antusias siswa dalam belajar bertambah, antusias siswa dalam memperhatikan penjelasan guru, siswa lebih berani dalam mengutarakan pendapat, kerja sama antarkelompok semakin aktif, dan siswa lebih termotivasi dalam belajar, serta siswa lebih mudah memahami dan lebih mudah dalam menyelesaikan masalah yang berhubungan dengan menghitung luas bangun datar. Hal tersebut dapat diketahui dari lembar pengamatan yang dilakukan guru dan observer, yaitu aktivitas guru dan siswa selama pembelajaran berlangsung ada peningkatan, terlihat siklus I ke siklus II dari nilai cukup baik ke nilai baik.

Adapun rata-rata hasil belajar juga demikian setelah adanya perbaikan pembelajaran dalam menghitung luas bangun datar menggunakan media potbangtar terlihat dari tes tulis siswa hasil evaluasi siklus I dan siklus II juga mengalami peningkatan dari siklus I 75, 61, dan siklus II 80,49 ini sudah melampaui dari KKM yang ditetapkan yaitu 70 . 
Meningkatnya rata-rata hasil belajar siswadari siklus I ke siklus II sebanyak 4, 88. Siswa yang tuntas dalam pembelajaran di siklus I telah mencapai 35 siswa dan siklus II 39 siswa dari 41 siswa secara keseluruhan. Sedangkan persentase ketuntasan belajar siswa juga mengalami peningkatan dari siklus I ke siklus II yaitu siklus I mencapai 85,37\% dan siklus II 95,12\%. Jadi meningkatnya persentase ketuntasan belajar siswa dari siklus I ke siklus II mencapai 9,75\%. Persentase ini juga telah melampaui dari yang ditetapkan yaitu $85 \%$

Peningkatan hasil belajar siswa dari siklus I ke siklus II dalam pembelajaran materi menghitung luas bangun datar dengan menggunakan media potbangtar dapat penulis gambarkan dengan grafik sebagai berikut.

Gambar 7: Grafik Peningkatan Hasil Belajar Siswa Siklus I dan Siklus II pada Pembelajaran Menghitung Luas Bangun Datar Menggunakan Media Potbangtar

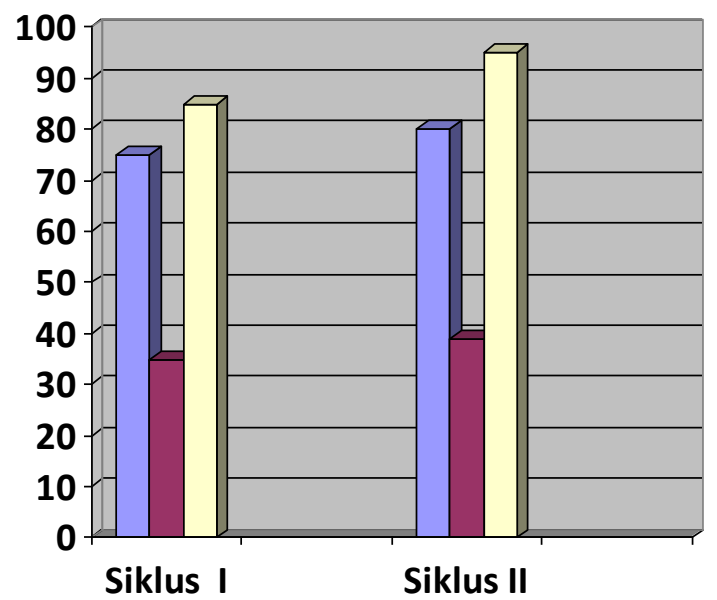

\begin{tabular}{|l|}
\hline Rata-rata \\
Hasil \\
Belajar \\
Siswa \\
Jumlah \\
Siswa yang \\
Tuntas \\
$\square$ Persentase \\
Ketuntasan \\
Belajar \\
\hline
\end{tabular}

Merujuk dari tabel tersebut dapat dijelaskan bahwa penggunaan media potbangtar dapat meningkatkan hasil belajar siswa dalam menghitung luas bangun datar. Grafik tersebut juga menjelaskan tentang 
peningkatan rata-rata hasil belajar siswa pada pembelajaran materi menghitung luas bangun datar setelah menggunakan media potbangtar, terlihat mulai dari siklus I ke siklus II dari 75,61 meningkat menjadi 80,49, sudah melampaui dari KKM yang ditetapkan adalah 70. Ketuntasan belajar siswa dari siklus I ke siklus II juga mengalami peningkatan dari 85, $37 \%$ meningkat menjadi $95,12 \%$. Ketuntasan belajar siswa inipun juga sudah melampaui dari persentase ketuntasan belajar yang telah ditetapkan yaitu $85 \%$.

Berdasarkan uraian hasil obsevasi dan rekap hasil belajar siklus I dan siklus II tersebut maka penulis dan observer menyimpulkan media potbangtar sangat efektif dalam meningkatkan hasil belajar siswa pada materi menghitung luas bangun datar.

\section{Penutup}

Berdasarkan hasil penelitian yang telah dipaparkan diatas, bahwa media potbangtar sangat efektif dalam pembelajaran matematika terutama materi menghitung luas bangun datar, sehingga dapat meningkatkan hasil belajar siswa kelas V SDN MIJI 4 kota Mojokerto. Peningkatan ini ditandai dengan rata-rata hasil belajar siswa dari siklus I 75,61, meningkat di siklus II 80,49, dan peningkatan ketuntasan belajar siswa dalam setiap siklus meningkat, yaitu siklus I 85,37 \%, siklus II meningkat menjadi 95,12 \%. Aktivitas siswa juga meningkat ditandai dengan antusias siswa dalam memperhatikan penjelasan guru, aktif mengajukan pendapat atau menjawab pertanyaan, aktif bekerja sama dengan kelompok.

Dari hasil penelitian tersebut, agar proses belajar mengajar matematika lebih efektif dan lebih memberikan hasil yang optimal bagi siswa, maka disarankan (a) Guru lebih sering melatih siswa dengan berbagai model dan media pembelajaran, walau dalam taraf sederhana, seperti penggunaan media potbangtar, sehingga siswa dapat menemukan pengetahuan baru dan berhasil memecahkan masalah-masalah yang 
dihadapinya; (b) Penggunaan media atau inovasi media dalam setiap pembelajaran perlu untuk mata pelajaran yang lain.

\section{Ucapan Terima Kasih}

Saya ucapkan terima kasih kepada (1) Kepala Sekolah SDN Miji 4 kota Mojokerto yang telah memberikan izin dalam penelitian, (2) Bapak dan ibu guru SDN Miji 4 Kota Mojokerto yang membantu kelancaran penelitian dan terselesaikannya artikel ini. Semoga hasil penelitian ini bermanfaat untuk kemajuan dan peningkatan pendidikan di kota Mojokerto khususnya dan pendidikan nasional umumnya.

\section{Daftar Referensi}

Agus, S. (2010). Coorporative Learning. Yogyakarta: Pustaka Pelaar.

Arikunto, S. (2012). Dasar-dasar evaluasi Pendidikan. Jakarta: Bumi Aksara. Arsyad, A. (2011). Media Pembelajaran. Jakarta: Rajawali Pers.

Edition.Victoria: Deakin University.

Hardianto, H. (2019). Conducting Quality Culture in Educational Institutions. Jurnal Ilmiah Peuradeun, 7(2), 257-268. doi:10.26811/ peuradeun.v7i2.210

Jihad, A. dan Abdul Haris. (2012). Evaluasi Pembelajaran. Yogyakarta: Multi Presindo.

Kemmis, S \& Mc Taggart, R. (1988). The Action Research Planner, Third

Rayandra, A. (2012). Kreatif Mengembangkan Media Pembelajaran. Jakarta: Gaung Persada Press.

Siswanto, R., Sugiono, S., \& Prasojo, L. (2018). The Development of Management Model Program of Vocational School Teacher Partnership with Business World and Industry Word (DUDI). Jurnal Ilmiah Peuradeun, 6(3), 365-384. doi:10.26811/peuradeun.v6i3.322

Wati, E. R. (2016). Ragam Media Pembelajaran. Jakarta: Solusi Distribusi. 
Vol. 5, No. 1, Maret 2021 